AperTO - Archivio Istituzionale Open Access dell'Università di Torino

\title{
Exploring grammaticalization from below
}

\section{This is the author's manuscript}

Original Citation:

\section{Availability:}

This version is available http://hdl.handle.net/2318/127895

since

Publisher:

Mouton de Gruyter

Terms of use:

Open Access

Anyone can freely access the full text of works made available as "Open Access". Works made available under a Creative Commons license can be used according to the terms and conditions of said license. Use of all other works requires consent of the right holder (author or publisher) if not exempted from copyright protection by the applicable law. 


\section{Trends in Linguistics}

Studies and Monographs 158

\section{Editors}

Walter Bisang

Hans Henrich Hock

(main editor for this volume)

Werner Winter

Mouton de Gruyter

Berlin · New York

\section{What makes Grammaticalization?}

\section{A Look from its Fringes and} its Components

\section{Edited by}

Walter Bisang

Nikolaus P. Himmelmann

Björn Wiemer

Mouton de Gruyter

Berlin · New York 


\section{Exploring grammaticalization from below*}

\section{Livio Gaeta}

\section{Introduction}

Grammaticalization has been a hot subject of research in diachronic and typological linguistics in the last two decades. Recently, the specificity of grammaticalization as an autonomous and peculiar kind of language change has been questioned (cf. Campbell 2001; Campbell and Janda 2001; Joseph 2001). Although grammaticalizationists firmly believe that grammaticalization is an oriented phenomenon whereby more lexical structures tend to become more grammatical, i.e. (bound) morphemes, and in later stages simply phonemes due to phonogenesis (cf. Hopper 1994), it has been objected that a number of counterexamples to unidirectionality exist (cf. Newmeyer 1998: 260-275, Campbell 2001; Janda 2001; and Heine 2003 for a survey). Moreover, what is usually counted under grammaticalization can be traced back to different fairly well known phenomena, such as reanalysis, semantic bleaching, etc. Therefore, grammaticalization can be at best considered an epiphenomenon of independent changes that take place for a number of different reasons and in different ways. In this perspective, grammaticalization turns out to be a mere fall out involving syntactic structures that happened to lose constructional transparency. Therefore, there is no diachronic tendency towards building up grammar. Although I believe that the objections raised against grammaticalization as an autonomous kind of language change are essentially correct, I am not in agreement with discarding grammaticalization as a general perspective under which language changes can be considered. In fact, what in my view is the main force of grammaticalization studies is the finding that grammar is not (merely) a messy aggregate of fortuitous changes, that yield a completely arbitrary structure. On the contrary, language change, and the grammaticalization perspective, tell us that a lot of apparently messy structures are the result of very well motivated changes that, far from being whimsical, shed (at least some) light on the way language users perceive the world around them and on the language they use to express it. ${ }^{1}$ As I hope will become clear in the rest of the paper, the light shed by grammaticalization on the apparently arbitrary structure of grammar is not only valuable for changes affecting the lexicon-to- 
grammar cline, but also for changes regarding the other source of grammatical structure, the phonology-to-grammar path. In fact, the approach adopted here is polycentristic: different sources for grammar are considered, one being the lexicon, and the other being phonology. In essence, this idea shares on the one hand Joseph and Janda's (1988: 195) assumption that "morphologization describes any transition (via dephonologization or desyntacticization) from a state in which a generalization is nonmorphological in nature to a state in which the corresponding generalization is morphological in nature", and on the other Dressler's $(1977,1985)$ idea that there are in the speakers' competence several centers or modules, each of them functioning in an autonomous way, i.e. obeying different principles. A crucial point is moreover morphocentricity: Morphology is held to be the central component of grammar, since "there is no aspect of grammar which interacts with all the others to the extent that morphology does" (Joseph and Janda 1988: 203). The paper is structured as follows: Section 2 explores the phonology-to-grammar path, discussing aspects and problems relating to the grammaticalization of sound alternations; Section 3 discusses the central role of morphology, emphasizing the centripetal nature of language change, even though allowing for occasional instances of centrifugal changes. The final Section 4 draws the conclusion.

\section{The phonological way to grammaticalization}

Textbooks on grammaticalization usually assume that there are basically two clines (or pathways) for lexical items to become more grammatical (Hopper and Traugott 1993: 7):

- content item $>$ grammatical word $>$ clitic $>$ inflectional affix

- content item $>$ grammatical word $>$ (compound) $>$ derivational affix

Examples for such changes are indeed dozens; classical cases are the following ones, taken respectively from Greek (Hopper and Traugott 1993: 24), where the future tense morpheme tha comes from an older construction thelo ina 'I wish that', and from German where a new suffix -tel has developed from old nominal phrases (= NPs) containing the lexeme Teil 'part' as head:

(1) a. thelō hina $>$ thelo $n a>$ the $n a>$ tha

Tha têlēphōnēsō tou patéra mou 'I will telephone my father'

b. Dritter Teil, Vierter Teil > Drit-tel 'a third', Vier-tel 'a quarter'
The Greek example represents the cline of grammaticality, with the full predicate becoming a case marker, whereas the German example represents the cline of lexicality, since the new suffix can be counted among the word formation devices of German. Given these very well known cases, ${ }^{2}$ in the following sections we will explore the possibility and the limits of the phonological clines to grammaticalization (cf. Gaeta 1998). Indeed, Greenberg (1991: 303) quite clearly states that

As with grammatical items, there is the possibility of interpretation of phonological items as having a grammatical significance, e.g. umlauting in German This might be called grammaticalization from below. It is, compared to the grammaticalization of lexical items, relatively infrequent and often a subsidiary method which accompanies others of the more common type. Nevertheless, its properties as compared to that of grammaticalization of the more usual type are I believe well worth exploring.

Far from being infrequent and subsidiary, this grammaticalization from below is usually called morphologization in the linguistic tradition, as if the root "grammar", and the derivatives "grammatical", "grammaticalization", etc., should be reserved for other (more important?) uses: apparently what comes from phonology can only have the modest goal of becoming morphological. See for instance the following quotation from Wurzel (1980: 444):

morphologizing, as we understand it, holds whenever a rule, which so far has held for an operation of permutation, insertion or deletion in a phonological context $\mathrm{P}$, changes in a way that it holds for the same operation (not necessarily only this one) or its inversion in a context of grammatical categories C. A rule, whose original (more or less preserved) function it was to adapt a set of phonetic sequences to human speech organs, takes over the basically new function of formally marking grammatical categories in words. Thus the complete or partial phonetic motivation of the rule is substituted by a semiotic motivation.

One cannot help agreeing with the spirit and the practice of this definition, that is widely shared by other scholars. Discussing morphophonologization, van Coestem and McCormick (1990: 333) for instance observe that "[t]he conditioning may develop from phonological to morphological, with the possible implication that the rule is partly phonological and partly morphological. When this occurs, it is viewed as a development to "morphologization"'. Klausenburger (1994: 2562) even warns the reader that morphologization, that is defined as "the historical rapport between phonology and morphology", "is not to be confused with "grammaticalization", the process 
of converting regular lexical items and structures into conventionally interpreted grammatical morphemes". Nevertheless, I do not see any good reason, except for inveterate custom, for calling such changes morphologizations, instead of grammaticalizations. Moreover, the usage of the term "morphologization" is more idiosyncratic than one would think after more than a decade of studies. For instance, the late Wurzel (2000: 12) firstly defines "Grammatikalisierung" as the process according to which "[sich] Wörter mit einer ursprünglichen lexikalischen Bedeutung in einem ersten Schritt zunächst zu "grammatischen Wörtern" [entwickeln]. Diese tendieren dann längerfristig dazu, ... . sich also zu morphologischen Markern weiterzuentwickeln". Subsequently, however, the author remarks that "[es, i.e., Old Icelandic, LG] nicht nur keine Flexionsmorphologie abgebaut, sondern durch Morphologisierung, d.h. durch die Entwicklung von syntaktischen Fügungen zu morphologischen Formen, neue Morphologie herausgebildet [hat]". In a similar way, McMahon (1994: 69), discussing syntactic features that may also become morphological, speaks of a "process of morphologization of syntactic elements, known as grammaticalization". ${ }^{3}$ Therefore, given that the outcome of such changes is basically the same, it sounds heuristically inadequate to have two terms for changes leading to similar results, i.e. an increase of morphology, unless we do not want to make a principled distinction between phonology-originating and lexicon-originating morphology. ${ }^{4}$ Moreover, not everything that comes from phonology becomes, strictly speaking, morphology: as will be illustrated below, we may also have processes of (morpho) syntacticization.

\subsection{Grammaticalization of phonological rules at the word level}

As the clines shown above indicate, what one expects to find when imagining possible phonological sources of grammar is that early phonologically-governed alternations become opaque, in the very specific sense that they lose phonetic motivation. ${ }^{5}$ Morphological conditioning enters into the triggering context; as a consequence of further phonological changes obscuring the initial motivation what emerges at the end is simply an affix-like alternation:

- phonological rule $(=\mathrm{PR})>($ morphophonological alternation $)>$ affix

Here the parallel is with a pre-grammaticalization stage where a discoursebased construction starts with becoming routinized, which has as an effect the loss of its pragmatic force and of its semantic motivation. Likewise, phonet- ics motivates the Lautsubstitutionen, and the routinization of such Lautsubstitutionen starts with the increasing opacity of the triggering context. ${ }^{6}$ At a certain point, this routinization, i.e. the introduction of a more abstract motivation for sound alternation, exceeds the limit of the phoneme/allophone iconic relation, which is used in semiotically-based approaches such as Andersen's $(1973,1980)$ and Dressler's $(1980,1985)$, and serves a motivation of a different nature. A Paradebeispiel for such a change is the Germanic umlaut mentioned above by Greenberg, where an original vowel harmony may lose phonetic motivation and acquire a purely morphological one:

(2) foot $\rightarrow$ feet, goose $\rightarrow$ geese

$$
\begin{aligned}
& F u \beta \text { 'foot' } \rightarrow \text { Fü } \beta \text { ' 'feet', Vater 'father' } \rightarrow \text { Väter 'fathers' } \\
& \mathrm{V} \rightarrow[+ \text { front }] /\left[\begin{array}{c}
- \\
+ \text { noun } \\
+ \text { plur. }
\end{array}\right]
\end{aligned}
$$

Diachronically, it was the weakening of unstressed vowels that made the triggering context opaque, giving start to the successive morphophonologization of the sound alternation. At the very end of the process, what we are left with is a substitutive morpheme, that marks an inflectional category, i.e. plural. The case of Germanic umlaut can be treated as specular with respect to the lexicon-to-grammar cline of grammaticality, whereas the following case drawn from Lahu is a good candidate for a specular cline of lexicality, since the emerging affix-like sound alternation expresses a derivational category, i.e. causativity: ${ }^{7}$

(3) dう̀ 'drink' : (*sdo >) to 'give to drink'

$$
\begin{aligned}
& d \grave{\varepsilon} \text { 'come to rest' }\left({ }^{*} s d \varepsilon>\right) t \varepsilon \text { 'put down' } \\
& m \grave{\partial} \text { 'see' }\left(*^{*} s m s>\right) m s \text { 'show' } \\
& c \hat{a} \text { 'eat' }(* s c a>) c \bar{a} \text { 'feed' }
\end{aligned}
$$

Here the original prefix that carried the derivational meaning has disappeared; however, its effect has not, since the actual alternation is the result of an assimilatory rule of devoicing accompanied by a tone lowering. Matisoff (1991) calls this phenomenon Cheshirization, like Lewis Carroll's Cheshire Cat, which disappeared leaving only its smile:

(4)

$$
\mathrm{T} \rightarrow[- \text { low }] /\left[\begin{array}{c}
- \\
+ \text { verb } \\
+ \text { caus. }
\end{array}\right]
$$


Sure, these examples can also be interpreted, as explicitly stated by Lehmann (1995: 149), as instances either of Hopper's (1994) phonogenesis or simply of morpheme erosion due to coalescence. In fact, the sound alternations that we observe synchronically are only the traces left by the original affixes. However, this interpretation overshadows the fact that a reanalysis has taken place, whereby an originally phonetically motivated alternation has carried over a new (semiotic, recall Wurzel's quotation above) motivation. As for umlaut, for example, the reanalysis has a central role in determining the autonomization of the former sound alternation due to vowel harmony. According to Ronneberger-Sibold (1990: 198), "wurde [der Umlaut] als Index für Plural-/-ə/ interpretiert, und als solcher war er natürlich um so wichtiger, je schwächer die Endung realisiert wurde". In fact, it was in those cases where umlaut occurred in Middle High German in combination with a plural suffix /-ə/ that it could acquire an indexical function of signaling plural. The disappearence of the suffix due to radical final schwa deletion favored the reanaly$\operatorname{sis}^{8}$ of the index as plural marker, as represented by the following schematization (cf. Ronneberger-Sibold 1990: 195):

Old identity New identity

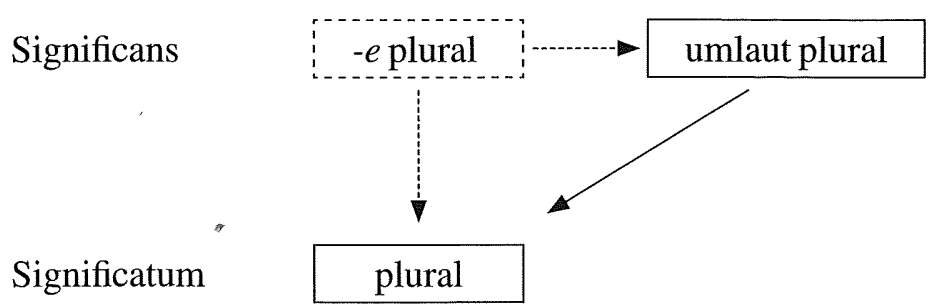

Nevertheless, reanalysis is not sufficient for grammaticalization of a phonological rule to take place. What is also necessary is the presence of a new semiotic motivation, as in Wurzel's definition given above. Let me be more clear with an example. In the French northern dialect of Jersiais (cf. Morin 1986 178), the reanalysis of a final consonant as a plural marker is attested in cases like [lavœ:] 'washer', pl. [lavœr], [sœ] 'sure', pl. [sœr], etc. This plural suffix has also been sporadically extended to other stems: [sœ] 'elder-tree', pl. [sœr]. The reanalysis is a consequence of a regular phonological change, that in Old French $(=\mathrm{OF})$ deleted final $/ \mathrm{r} /$ : OF mer 'sea' $>$ [me], except when followed by another (later deleted) consonant: OF merc 'land mark' > [mer], OF cors 'body' $>$ [cor], etc. Therefore, $/ \mathrm{r} /$ was prevented from deletion in the plural by the regular plural suffix $-s$, which thereafter also underwent deletion. The remaining $/ \mathrm{r} /$ of the plural was then reanalized as a plural marker instead of the earlier $-s$. Thus, we have here a simple boundary shift: as a response to the deletion of phonemes, the morphological boundary has moved leftwards, recreating the preceding root+suffix scheme:

Significans
Significatum
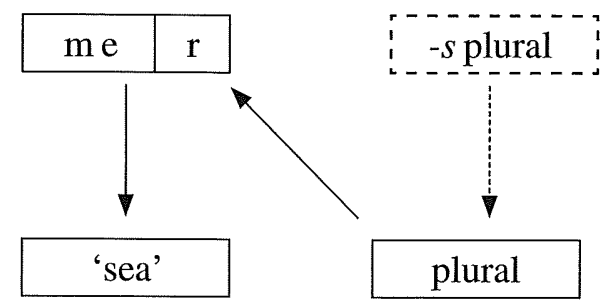

A further somewhat similar example of reanalysis without semiotic remotivation (that can also be considered as an instance of phonomorphogenesis, $s$. note 16 below) is provided by the German plural suffix -er (cf. Geld 'money'Gelder) that was in Old High German a stem formative to which an inflectional suffix was added (cf. OHG chelb-ir-es 'calf-GEN.SG' chelb-ir-o 'calfGEN.PL'). As a consequence of reanalysis triggered by the loss of unstressed final vowels, the stem formative turned out to acquire plural meaning, and disappeared from the singular that was leveled out on the basis of the other $a$-stem neuters like wort 'word' (cf. Gaeta 2002).

Comparing German umlaut with the cases drawn from French and from Middle High German, we observe the same contrast highlighted by Vincent (1995: 437) between grammaticalization and exaptation

$\begin{array}{lll} & \text { Form } & \text { Content or Function } \\ \text { grammaticalization } & \text { NEW } & \text { NEW } \\ \text { exaptation } & \text { OLD } & \text { NEW }\end{array}$

Whereas in the case of the French dialect of Jersiais and in the case of Middle High German discussed above, we have a sort of exaptation, since old linguistic material is exploited for new uses, in the other cases we have the use of newly-created sound alternations for new (grammatical) functions. It is important to stess here that "the phonetic material which makes up the form side of the grammaticalizing item is inherited, therefore in one sense 'old'. However, it is new RELATIVE TO THE GRAMMATICAL SYSTEM, and this is the crucial point" (Vincent 1995: 437). On the other hand,

[c]hanges catalogued under the rubric of exaptation, by contrast, involve the assignment of new morphosyntactic functions to elements which are already centrally part of the grammar, and typically part of the paradigmatic core of 
the morphological system. Such changes are different too from the later stages of grammaticalization, in that they involve shifts between non-adjacent areas of morphological meaning or function. They involve, to coin a term, the 're-grammaticalization' of a particular morphological marker rather than its continuation down the grammaticalization path on which it was historically embarked". (Vincent 1995: 438)

This 're-grammaticalization' distinguishes the changes observed in the case of the French dialect of Jersiais and of Middle High German from the creation of a new semiotic motivation for the umlaut rule. ${ }^{9}$

For the reanalysis to take place, it is not always necessary to despoil the corpse of a dead morpheme. In the Mid-Italian dialect spoken in Rieti (Campanelli 1896: 64, 208), gender was explicitly expressed by suffixes (cf. murator-e 'bricklayer-M.SG.' vs. murator- $a$ 'bricklayer-F.SG'). In the feminine form a lowering rule affected mid-high vowels when followed by a low vowel, especially in the presence of the agent noun suffix -tor-; a further raising rule affected mid-high vowels when followed by high vowels giving rise to the following paradigm:

(8) mura'tor-e 'bricklayer-M.SG' vs. mura'tor-a 'bricklayer-F.SG' mura'tur-i 'bricklayer-M.PL' vs. mura'tor-e 'bricklayer-F.PL',

However, the lowering effect on the preceding mid-vowels due to the final - $a$ was reanalysed so as to carry the gender opposition in sa'lera 'salt-seller.F' that contrasts on the one hand with sa'lera 'salt-cellar', where the sound alternation is made opaque, and on the other with the masculine sa'lere 'saltseller.M'. A further similar change is assumed by Haiman (1998) for the development of infixation in Khmer. In his reconstruction, infixation in action nouns like $d$-əmn-aə 'voyage' $\leftarrow d a$ ə 'to walk', $c$-sm-laəj 'answer $(\mathrm{N})$ ' clazj 'answer' is the result of a process of "secretion or morphogenesis", that started with the radical phonological reduction of the first anacrusic syllable still observable nowadays in casual speech in iambic words like boy' kaət 'originate' $\rightarrow$ bəy'kaət $\rightarrow$ pə'kaət, pram'buəj 'eight' $\rightarrow$ pram'buəj $\rightarrow$ pəm'buəj, etc. (cf. Haiman 1998: 606). Once that the full and the reduced form came to coexist, "by a natural and often documented tendency to assign different meanings to minimally contrasting forms, some meaning would be assigned to the fleeting coda of the anacrusic syllable. ... Later perhaps, by an equally natural iconic tendency to assign more meaning where there is more form, the reduced form would be treated as the underlying verb and the more complex form as a derived noun" (Haiman 1998: 612). As an evidence for his explan- ation, Haiman quotes a handful of pairs of Khmer words with nearly identical meaning, as in $c($ omn $) a h$ 'ripe, mature', $s(J m) d a c$ 'prince', and compooh 'towards', where these pairs represent the initial stages of the patterns subsequently grammaticalized. Thus, in these cases a new semiotic motivation is extracted from sound alternations developed in a fairly natural way. For Khmer, a crucial role is further played by the peculiar word-prosodic model that favored the reanalysis of a reduced $\{\mathrm{CCVC}\}$ root in terms of $\{\mathrm{C}\}+\{\mathrm{CVC}\}$. Thus, it became possible for speakers of Khmer to reinterpret possible occurring codas in the first syllable as an insertion. ${ }^{10}$

\subsection{Grammaticalization of PRs at the level of phonological word}

To explore the typology of grammaticalization from below, one is faced with the different domains that can be covered by earlier phonological rules when they get grammaticalized. The domains must be understood under two different perspectives: the first perspective takes into consideration the phonological level at which the grammaticalized rules act. The phonological level is thus considered as a phonological domain expressing the place where a PR is (or was) applied. On the other hand, the phonological domain covaries with the syntactic scope of the grammaticalized rule (cf. Gvozdanović 1986: 50). In this sense, the basic word level is embedded into larger levels up to sentence or utterance level.

Clearly, the word level is the most basic; in the preceding section a number of examples of grammaticalized PRs ingenerating semiotically relevant sound alternations at the word level have been mentioned. This is also the level identified by Greenberg in the above reported passage. Moreover, we expect to find larger levels that are relevant for our perspective, i.e. the grammaticalization of PRs. Probably, the first level relevant for such an exploration of grammaticalized PRs is the phonological word (= PW), intended as a word plus possible clitics. This may either correspond to the internal structure of a syntactic constituent, or have effects on the immediately neighboring context. A larger domain is constituted by the phrase level, when for instance a sound alternation is crucially related to the boundary of a given phrase structure and expresses syntactic relations between the constituents. Finally, we expect to find cases where a sound alternation takes as scope the whole sentence, having acquired a semiotic motivation related to the type of utterance.

Before starting with cases of grammaticalized PRs at the PW-level, let me first discuss an example that illustrates how PRs undergo grammaticalization. In the two Tuscan neighboring towns Lucca and Pisa, we observe the 
following tiny, but consistent differences (cf. Marotta 1995):

(9)

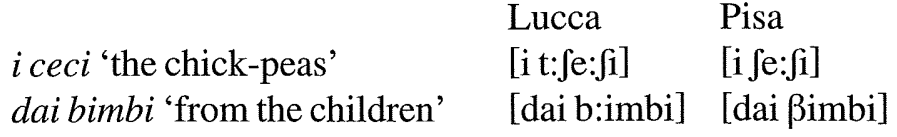

These differences are due to the serial application of Raddoppiamento Fonosintattico $(=\mathrm{RF})$ and of Gorgia

(10) a. RF

$$
\mathrm{C} \rightarrow[+ \text { long }] /\left[\begin{array}{c}
+ \text { def. } \\
+ \text { masc. } \\
\text { + plur. }
\end{array}\right] \#
$$

b. Gorgia: $^{11} \mathrm{C} \rightarrow[+$ cont. $] / \mathrm{V}(\#)$

These rules are in a bleeding order: in this way inital doubling prevents the lenition of the consonant. ${ }^{12}$ Moreover, another optional rule plays a role, namely Apocope:

$$
\text { Apocope: }\left[\begin{array}{c}
\text { +def. } \\
+ \text { masc. } \\
\text { +plur. }
\end{array}\right] \rightarrow \varnothing / \mathrm{V}\left[\begin{array}{c}
- \\
\text {-stress }
\end{array}\right] \#
$$

RF and Apocope contain the same morphological features: the morpheme marking definiteness, masculine gender and plurality $-i$. They clearly are morphophonological rules conditioned in their application by the surrounding morphemes. After the application of the three rules presented above, what turns out are the following outcomes:

a. 'I'm eating the chick-peas'

b. 'from the children' 'from children'
Lucca Pisa

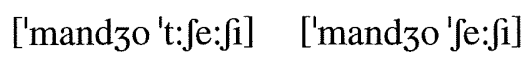

['mandzo' $\mathrm{fe}: \mathrm{j}]$ ['mandzo' $\left.\mathrm{ee}: \mathrm{fl}_{\mathrm{i}}\right]$

[da'b:imbi] [da' $\beta$ imbi]

[da' 'Bimbi] [da 'b:imbi]
A number of neutralizations come about, as for instance in the Pisa variety the neutralization of the opposition between the definite and the indefinite objects in (12a). Moreover, the preposition $d a$ 'from' is a RF-trigger in Pisa, giving rise to the inverse distribution of lenited and doubled forms with respect to the Lucca variety. Notice that in the latter the presence of the definite article in the sentences in (12a) can only be inferred on the basis of the RF affecting the initial consonant. This state of affairs suggests a possible scenario for grammaticalization: intertwining of morphological and phonological features, increasing opacity of distinctive morphological features that favors reanalysis. The last step is however not accomplished in these dialects: the block of rules do not give rise to a new semiotic motivation of the sound alternation, although creating the basic conditions for a reanalysis to take place. An example that points to a further step toward grammaticalization of a PR is found in other Italian dialects, namely in Calabria (cf. Loporcaro 1995: 547, 1997: 116). In these dialects, a similar rule of RF is triggered by the third plural present indicative suffix as in [" $\beta$ iru p:oku] 'they can't see well', that originates from Lat. *vidunt pocu. Synchronically, this rule gives rise to minimal pairs, when a homophonous ending occurs in the same context:

\section{(13) ['ruormu 'p:uru] vs. ['ruormu 'puru]} 'they also sleep' 'I also sleep'

Similar to what we have assumed before, this sound alternation can be represented by the following rule:

$$
\mathrm{C} \rightarrow \mathrm{C}: /\left[\begin{array}{c}
+ \text { verb } \\
+ \text { pres. } \\
3 \text { pers. } \\
+ \text { plur. }
\end{array}\right] \#
$$

Notice however that with respect to the similar rule from Tuscan dialects seen in (10) above this sound alternation is more abstract, notwithstanding the apparent formal identity. In fact, it is not merely related to a specific affix displaying a certain morphophonemic structure, but it is connected with the grammat ical category ' 3 rd person plural', since this ending was extended to the other inflectional classes, too. Thus, it is not $-u$ as such the trigger of RF, but the whole category ' 3 rd person plural', as in [' $\beta$ u ${ }^{1} \mathrm{u}$ k:antịnnu] "they fly singing", ['kuntu 'k:a:tsie] 'they tell lies', where a verbal ending - $a$ is expected since respectively from Lat. *volant, *computant (cf. Loporcaro 1995: 548, 1997: 116). The Tuscan and the Calabria cases are however strictly related, given that the neutralization described for Tuscan opens the door for further reanalysis in the Calabria variety to take place. A similar, but to a certain extent more abstract case since having no effect on the external context is reported for Breton, where in the standard language there is a lenition triggered by the masculine definite article $a r$, in a way similar to what we described above for Welsh: $k i$ 
[ki:] 'dog' vs. ar c'hi [ar xi:] 'the dog' (cf. Ternes 1986: 19). However, in the corresponding forms of the Breton dialect of Scaër (Sud-Finistère) the article has been dropped, leaving as its trace only the lenition of the initial consonant of the noun: [ki] 'dog' vs. [çi] 'the dog', so that we can now represent the sound alternation in a way similar to what we have seen in Section 2.1. for Germanic umlaut:

$$
\mathrm{C} \rightarrow[+ \text { cont. }] /\left[\begin{array}{c}
- \\
+ \text { masc. } \\
+ \text { sing. } \\
+ \text { def. }
\end{array}\right]
$$

\subsection{Grammaticalization of $P R$ at the phrase level}

The next domain in our exploration concerns the phrase level, intended both as a phonological domain larger than the phonological word and as a syntactic concept. Morphophonological alternations related to a syntactic domain can be found in Old Tamil, where "case markers and plural markers alike are often deleted so that the noun occurs in its stem or oblique forms even though case has been syntactically assigned to it" (cf. Lehmann 1998: 81). The doubling of the initial stop of the following word may indicate case-marker deletion:

(16) num ür.c $(<\bar{u} r-k k u) \quad$ cel-kam you (obl.) place $(<$ place-DAT) go-NPST.1PL

'We are going to your place.'

In this example the doubling stands for the deleted dative case marker. In Modern Tamil (cf. Steever 1987:734) this doubling is still preserved and triggered only by certain forms such as the dative case marker, the accusative marker and the demonstrative. However, doubling is nowadays only graphic: since doubled consonants were degeminated, a form like intap pāvam 'this sin' is realized as [inta pāvam]. Nevertheless, the original doubled consonants contrast synchronically with cases where doubling did not take place such as in inta pāvam 'this facial expression', pronounced [inta bāvam] because treated as a compound with word-internal intervocalic voicing.

A clearer example of an earlier PR that carried over a morphosyntactic function at the phrase level is provided once more by Welsh, where lenition affects an initial obstruent of a noun when the latter is direct object (= DO) and opens the NP (Awbery 1986: 418): ${ }^{13}$
(17) a. ['gweləð*w1n gi:]

'Wyn saw a dog.'

b. ['gwelっð* win ə ki:]

'Wyn saw the dog.'

Notice that only in the first case, when the NP is not opened by the definite article, the lenition is allowed. Moreover, the NP must play the role of DO, as shown by the following pair, where only in the second case the condition is met:

(18) a. clywodd gi

'S/he heard a dog.'

b. clywodd ci

'A dog heard.'

Thus, in this sound alternation, the position of the constituent plays a role, viz. the NP cannot be definite, but more important is the syntactic role played within the sentence, i.e. DO. Again, we can represent this alternation by means of the following rule, where the phrase-domain is decisive for the correct application:

$$
\mathrm{C} \rightarrow[+ \text { long }] /\left[\begin{array}{c}
- \\
+\mathrm{N} \\
+\mathrm{DO}
\end{array}\right]
$$

As a difference with respect to the cases examined in the preceding sections, the domain is here purely syntactic: the syntactic relation is marked within the NP independently of the preceding constituent. ${ }^{14}$

\subsection{Grammaticalization of PRs at the sentence level}

The scope of a grammaticalized PR can also be wider: in this sense it can be syntacticized. Syntacticization means here that, similar to what is usually assumed within classical grammaticalization examples, the domain of the sound alternation is syntactically determined, and the semiotic motivation of the rule is related to sentence level, not to word or constituent level as we have seen in the preceding sections. A good example of such a process of syntacticization is provided by the development of interrogative markers in French (Foulet 1921: 278-281; Brunot and Bruneau 1949: 37, 530; Harris 1978: 33). This 
linguistic change has been claimed to represent an instance of degrammaticalization (cf. Harris and Campbell 1995: 65-66; Campbell 2001: 132), since it involves the fate of earlier suffixes that have become clitics, i.e. have lost tightness with the host. However, even though it is clear that this change presupposes that something has moved toward syntax, i.e. more autonomy, I am not sure whether these authors have provided the correct interpretation of the facts. Let us first give a look at the French data, before drawing the conclusions. As already mentioned in Section 2.1. above, in French a PR of consonant deletion operated in the sixteenth century, and cancelled consonants in coda before pauses:

$$
\mathrm{C} \rightarrow \varnothing / \ldots \#
$$

The effect of this PR was that the suffix of the 3rd person singular of the verbs was deleted in prepausal position: il par ( $t$ ) 'he leaves', il partai ( $t$ ) 'he left', il aimai $(t)$ 'he loved'. The final consonant only surfaced in the interrogative form with the postposed clitic: part-il? [par'ti] 'does he leave?', partait-il? [parte'ti] 'did he leave?', aimait-il? [عme'ti] 'did he love?'. Notice that in this stage the singular forms il par $(t)$ [i'par] and il aime [i'lem(ə)] were opposed to the interrogative forms with inversion part-il? [par'ti] and aime-il? [ $\varepsilon^{\prime} \mathrm{m}(\partial) \mathrm{i}$ ] 'does he love?'. Subsequently, a rule inversion took place: where a deletion rule formerly occurred, the inverted insertion rule was abduced in presence of a postposed clitic pronoun:

$$
\varnothing \rightarrow t /\left[\begin{array}{c}
-. \\
+ \text { verb } \\
3 \text { pers. } \\
+ \text { interr. }
\end{array}\right] \#[\text { Pron. }]
$$

It was at this time in the sixteenth century that forms with non-etymological dental like aime-t-il?, aime-t-on?, etc. are attested. Later, in the nineteenth century, a further reanalysis took place in français populair: since it only surfaced in interrogative sentences, the (inserted or etymological) dental was taken to be part of an interrogative morpheme/ti/ and coherently extended to the whole verbal paradigm:

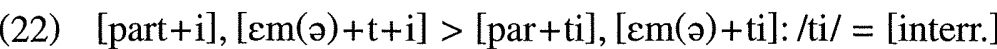
j'aime-ti?, tu aimes-ti?, il aime-ti?,... . je pars-ti?, tu pars-ti?, i par(t)-ti?,.. .
Thus, the new morpheme /ti/, which has been analysed either as a suffix (as in Picard 1992) or as a "particle" (as in Léard 1996), is not simply the old suffix of the 3rd person singular, as claimed by Harris and Campbell (1995): its story crucially intersected with the deletion rule and the subsequent rule inversion seen above. In fact, both the rule inversion and the reanalysis were a consequence of the increasing opacity of the segmental context firstly in prepausal position and subsequently before a postposed clitic. We can see the extraction of a new morpheme /ti/ as the ultimate response to this opacity.

A further case of an earlier PR that gave rise to a sound alternation grammaticalized at the sentence level is once more provided by Welsh, where in some varieties spoken in both north and south Wales (cf. Awbery 1986: 423) some lexical triggers may optionally be dropped, leaving the ingenerated lenition as the only trace of the original structure. As is shown by the following example, the interrogative particle /a/ may be present or missing; in both cases the first consonant of the verb undergoes a lenition (in this case radical deletion):

(23) a. ['gweləð*'win r'ðamwajn]

'Wyn saw the accident.'

b. [a 'welest ti $r$ 'ðamwajn?]

'Did you see the accident?'

c. ['welest ti r'ðamwajn?]

In the last sentence the interrogative function is entirely carried over by the deletion of the initial consonant of the verb.

The developments of earlier PRs shown in this section all have in common the new semiotic motivation developed as a result of reanalysis. We have discussed single cases going from the simple to the complex, namely from the more lexical domain of the word to the more complex level of the sentence. True, these examples can partially be reduced under the same label of the formation of new affixes, which are ultimately the result of great coalescence, as Lehmann (1995: 149) observes: "The greatest degree of fusion is reached in what has been traditionally called symbolism of the apophony (ablaut) and metaphony (umlaut) type, e.g. Engl. sing vs. sang (PAST) or foot vs. feet (PL)". However, on the one hand the new affixes are not always the remnants of earlier morphemes, as shown by examples (8) and (22) above. On the other, what we have described shows the range of possible meanings carried over by the affixes, that do not merely point to a degree of coalescence with the elements with which they have putatively fused, as in (16) and (19) above. Thus, the carrying over of semiotic motivation by a PR is distinct from the tendency shown 
by highly grammaticalized items toward becoming fused with lexical roots, where, as Lehmann (1995: 149) recognizes although with the necessary caveat, "the elementary necessary precondition for coalescence is that the grammaticalized item has some grammatical relation to the element with which it is to coalesce".

\section{Everything tends toward morphology}

What the preceding sections have attempted to show is that we can assume a similar and opposite cline of grammaticalization of PRs with respect to the traditional one starting with lexical items. Although there are clearly differences between the two types of phenomena, what they seem to share is the fact that both contribute, although in a different measure, to build the grammar, at least under the conception of grammar as something conventionalized without phonetic or semantic motivation. This sounds actually somewhat paradoxical, since it is not a mistery that morphology, besides being the Cinderella among the components of the faculté du langage, is surely the least "universal" among language components, and certain languages and linguistic types are claimed to not even show it. ${ }^{15}$ The paradox is however less controversial than it seems to be, if one realizes that morphology indeed makes use of very powerful means of expression, i.e. affixes, that are much more abstract than lexemes, and therefore allow to account for a much more general spectrum of meanings. This is evident for example in word formation where compounds usually display much more specific meanings related to the base meaning of the lexical units; as observed by Barz (1983: 67), in German, where composition is highly productive, for verb-noun compounds one can ascertain at least six different derivational meanings:

\section{(24) a. agentive: Schwimmkörper 'craft'}

b. instrumental: Schweißgerät 'soldering iron'

c. final: Trinkwasser 'drinkable water'

d. local/final: Schlafwagen 'sleeping car'

e. temporal: Feiertag 'holiday'

f. resultative: Schlagsahne 'whipped cream'

The spectrum of the possible (productive) derivational meanings is reduced to only two in the case of deverbal nouns, where the suffix -er covers a much more general meaning and is therefore compatible with a great number of bases:
(25) a. agentive: Schwimmer 'swimmer'

b. instrumental: Rasierer 'razor'

Similar arguments can be made for English gonna with respect to the original directional construction going to, or for the Romance future suffixes derived from the Latin construction Inf. + habere. Thus, what we see at stake here is the implementation of Bybee's (1985: 13-16) concept of relevance: as a result of grammaticalization, layering of different morphemic stacks comes into existence, where the different layers represent different levels of abstractness. Morphology is the (not always linear) result of such layering. This morphocentricity is recognized by Klausenburger (2000: 145) by means of the schema (26).

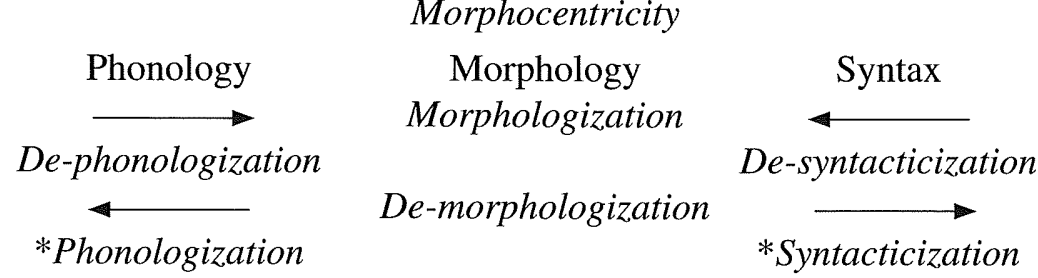

Klausenburger sticks to the traditional terminology that defines morphologization as the result of the increasing opacity of PRs, and is therefore distinct from grammaticalization. Accordingly, grammaticalization (and the reverse de-grammaticalization) are understood as synonymous of syntacticization (and of its opposite de-syntacticization). As shown above, this usage cannot cope with a number of dephonologizations that are not reducible to morphologizations; moreover this usage obscures the similar effect of bringing new morphology into existence from both sides, since it is not understandable why only syntacticizations should be worthy of being related to grammaticalization, i.e. emergence of grammar. Moreover, Joseph and Janda (1988) underscore what they call the morpholexical preference, that underlies the strong preponderance of cases of morphologizations with respect to demorphologizations. In fact, these authors avoid the broader term grammaticalization (cf. Section 1. above), and consistently employ the more specific morphologization, because "both "lower-level" phonological processes and "upperlevel" syntactic constructions (and/or processes) so often have morphology as the ultimate target of their diachronic development" (Joseph and Janda 1988: 207). Even though I share this morphocentric view, morphologization may appear too narrow a term for the changes I discussed in the preceding sections. Thus, my usage of the term grammaticalization is intended to comprise all the 
changes that entail an increase of the degree of abstractness of the elements involved as conventionalized structures. In this sense, umlaut as a plural marker in German is no less conventionalized than the basic word order in the Romance languages with respect to Latin. Far from obscuring the central role of morphology, my usage intends to focus on morphocentricity by considering grammaticalization as a general drift toward grammar-core building, viz. morphology.

Furthermore, another peculiar factor highlighted by Klausenburger's schematization that plays a central role in morphocentricity is directionality. Tendentially, phonetically or discourse-motivated linguistic material turns out as conventionalized grammatical structure. However, the claim of directionality must not be understood sharply. Recently, several counterexamples to directionality have been mentioned that question the validity of this concept (cf. Joseph and Janda 1988; Campbell 1991, 2001; Newmeyer 1998: 260 275, Janda 2001; Joseph 2001; Norde 2001). Nevertheless, it seems to me that at least two points must be made clear, when discussing directionality. On the one hand, the result of a grammaticalization is irreversible in itself: since grammaticalization represents the conventionalization of formerly motivated structures, we do not expect to find the remotivation of exactly the same structure going back to the original state. The reason for this irreversibility is based on the countericonic nature of conventionalization, as pointed out by McMahon (1994: 171):

Paradoxically, as the grammaticalising form weakens, becoming more integrated into the construction but losing more of its own identity, it becomes gradually less iconic, and develops into a symbol of its particular construction, at which point its independent, iconic origins are no longer perceived. It follows that a change motivated initially by iconicity in the syntax, and specifically by the spatial proximity of semantically related elements, eventually contributes to the rise of symbols. Grammaticalisation, in other words, is the gradual fusion of icons into symbols, and the weakening processes involved in grammaticalisation involve a shift from the iconic to the symbolic. It is this link with iconicity that leads to the essentially unidirectional but cyclic nature of grammaticalisation.

Clearly, this statement is only valid in the best possible world: as Joseph (2001) reminds us, there can be distortions in the transmission of a language change similar to what happens in lexical diffusion; in such cases, a change can stop and we may observe in a successive stage the reestablishing of the preexistent state of affairs.
On the other hand, the contention on directionality must not be seen as a yes/no question. In fact, everybody would agree upon the fact that "demorphologization [i.e., in our terms: degrammaticalization, $L G$ ] is generally held to be a rare phenomenon" (Joseph and Janda 1988: 198). Even though single cases of degrammaticalization may be attested, they are by far a minority with respect to the cases of conventionalization, as recognized by the otherwise sharply critic Newmeyer (1998: 275-278). I will mention here only two instances of degrammaticalization with different targets: respectively, phonology and syntax. As a case of rephonologization, one of the few clear-cut examples comes from French, where Morin, Langlois and Varin (1990) investigate the fate of a rule of tensing that came about as a consequence of a compensatory lenghtening that affected vowels occuring before obstruents deleted in complex codas: we can represent the effect of deletion plus compensatory lengthening in autosegmental terms by means of a reassociation of the vowel with two units on the X-slot:

(27) croc 'hook' [krok], pl. crocs [kro:s]

$$
\begin{aligned}
& \mathrm{k} \text { 。 } \mathrm{s} \\
& |\mathrm{|}| \mathrm{|} \mid \\
& \mathrm{XXXXX}
\end{aligned}
$$

Thereafter, the already mentioned rule of final consonant deletion (cf. Section 2.4. above) was accompanied by the tensing of remaining final nonhigh long vowels:

(28) croc [kro], crocs [kro:] $\left[\begin{array}{c}\mathrm{V} \\ - \text { high } \\ + \text { long }\end{array}\right] \rightarrow[+$ tense $]$

At this point, after the neutralization of the word-final length, the tensing rule was grammaticalized, since it was reanalysed as a marker of plural:

(29) sot 'silly' [so], pl. sots [so]

$$
\left.\left[\begin{array}{c}
\text {-high } \\
\text {-low } \\
+ \text { back }
\end{array}\right] \rightarrow[+ \text { tense }] / \_\right]_{\mathrm{N}, \mathrm{A}[+ \text { plur }]}
$$

However, this grammaticalization was subsequently destroyed by the radical extension of the tensing condition to the singular forms: 


$\operatorname{sot}[$ so $]$, sots $[\mathrm{so}]\left[\begin{array}{c}\mathrm{V} \\ - \text { high } \\ - \text { low } \\ + \text { back }\end{array}\right] \rightarrow[+$ tense $] /[]_{\mathrm{N}, \mathrm{A}}$

Morin, Langlois and Varin (1990: 516) call this process "phonologization", since it represents "the progressive generalization of a morphophonological rule through deletion of the morphological specification limiting its range of application". Synchronically, we are left with a condition on possible final vowels which determines the sound alternation between the masculine sot [so] and the feminine sotte [sot]. Although this interpretation in terms of phonologization of a morphologized sound alternation may be valid (but see the criticism in Dressler 1996: 78), this example nicely illustrates what I assumed before as irreversible in grammaticalization changes. In fact, the new phonological rule or condition on final vowels does not reestablish the earlier PR represented in (28) above; rather, it represents a new condition on French phonology, that has nothing to do with the former morphophonological rule, as pointed out by Klausenburger (2000: 144). A second case of degrammaticalization is taken from Newmeyer (1998: 266), who mentions as an example of an affix upgrading to clitic status the development of the Old Norse genitive suffix $-s$ in Norwegian (and other Scandinavian languages such as Swedish, cf. Norde 2001), where it functions, as in English, as a clitic marker on the full NP:

(31) a. Pers bil

Peter's car ,

b. ${ }_{\mathrm{NP}}\left[\mathrm{NP}_{\mathrm{NP}}[\right.$ den gamble mannen med skjegget $]$ s hus $]$

the old man-the with beard-the's house 'the old man with the beard's house'

c. Hvem erdet's (bil)?

who is it-s (car)

'Whose (car) is that?'

In many idiolects, $-s$ can also be stranded, cliticizing to the element preceding it (cf. (31c)). Here, an analysis as an affix is impossible. Notice that it is impossible to explain away this upgrading as influenced by possessive constructions containing the possessive (reflexive) pronoun such as Per sin bil 'lit. Peter his (refl.) car', as can be done for English (cf. Lehmann 1995: 18, Janda 2001: 301303 , and the discussion in Norde 2001: 254), since the Scandinavian $-s$ had not become homophonous with any pronoun and, at least for Swedish (cf. Norde 2001: 255), such constructions as Peter his car were scarcely relevant.
This second example illustrates another point that in my opinion needs to be taken up when speaking of grammaticalization. In fact, critical voices against the directionality hypothesis show that, in contrast with an ideally funnel-shaped grammaticalization channel, there are indeed changes that have the effect of shifting material from the center of morphology to the borders. To mention just a few examples, the reader is referred to the suffix of the present participle in Italian (and other Romance languages) -ante that has become a marker for agent nouns, also applicable to nouns (cf. braccio 'arm' $\rightarrow$ bracciante 'laborer', negozio 'shop' $\rightarrow$ negoziante ‘shopkeeper', cf. Luraghi 1998). Another similar case is provided by the marker of the old so-called long infinitive in Romanian (cf. exprima 'to express' $\rightarrow$ exprimare 'expression', cf. Carabulea and Popescu-Marin 1967; Fischer 1989: 34) that has become a suffix for action nouns, undergoing lexical restrictions typical of derivational suffixes. For instance, a suffix -are was extracted from the most productive inflectional class and employed to derive action nouns from verbs of other inflectional classes as in naşte 'to bear, be born' $\rightarrow$ născare and zăcea 'to lie' $\rightarrow$ $z \breve{a c}$ are. Moreover, in several cases the productivity of the suffix -re is blocked by the presence of other action nouns derived by means of other suffixes as in moarte 'death' that blocks the possible *murire $\leftarrow$ muri 'to die'. As is well known, inflectional rules are usually not subject to such lexical blockings.

On the other hand, similar shifts to the specular border morphology/phonology are also numerous. As an example, the well known instance of grammaticalization of the Latin construction lentā mente 'with a slow mind' can be mentioned. In this respect, it is scarcely noted that the rise of the new Italian suffix -mente also involves a degrammaticalization of the early case marker of the adjective that has lost its inflectional status becoming a root-conditioned allomorphy as in lenta-mente 'slowly' vs. sottil-mente 'subtly'/frequentemente 'frequently'. Notice that the last allomorphy is also extended to adverbs such as violente-mente from violento 'violent', even though a feminine form violenta is theoretically available. Moreover, a similar demorphologization concerns also the Latin inchoative suffix -isc- (cf. Rudes 1980), whose occurrence in Italian and in other Romance languages is now related to the presence of stressless inflectional suffixes (fin-ísc-o 'I end' vs. fin-iámo 'we end'). ${ }^{16}$

It is important to stress that the increase in phonological conditioning is to be interpreted as phonemicization (similar to Hopper's phonogenesis), not as a real phonologization, i.e. as an increase in the phonetic motivation of an alternation. ${ }^{17}$ In this sense, the phenomenon is specular to what is usually called lexicalization. The increase of lexical or phonological conditioning can be viewed as a loss in morphocentricity. Both phenomena have in common the loss of paradigmaticity, which is peculiar of morphology, and the rise of 
isolated forms. Given the strong tendency of complex systems toward more generality, we do not expect to find massive cases of phonemicization and of lexicalization, at least in absence of catastrophic changes within a linguistic tradition such as language death or extensive language contact. Thus, shifts are possible, even though sparse, but we do not expect to find massive cases leading to isolation of early paradigmatic oppositions.

\section{Conclusion}

To summarize the discussion put forward in the preceding sections, what emerges from the picture is morphocentricity: only under this perspective can grammaticalization be correctly interpreted as a cover term for changes that have in common the formation of conventionalized structures. From this viewpoint, the hypothesis on directionality is a side-effect of the reduction of iconicity as a consequence of the routinization and of the conventionalization of the speech acts. In fact, conventionalization deprives early phonological or lexical units of phonetic or semantic motivation. This does not exclude that the conventionalized units may be further reemployed for other purposes. In this sense, for example, changes converting inflectional into derivational morphology are not surprising. However, neither can a fully conventionalized structure be reported to its iconic stage (and in this sense grammaticalization is irreversible), nor can a highly abstract and general system be massively reduced to isolated phonemic or lexical relics. Grammaticalization from below draws the attention on the centripetal nature of language change: morphology is massively produced by means of independent forces, that contribute to the increasing opacity of frequently employed linguistic structures. Thus, it is more appropriate to speak of centripetal directionality, rather than of a highly problematic unidirectionality. Grammaticalized PRs may reach several domains of complexity exceeding word-level: however, they usually remain within the scope of morpho-syntax, since conveying grammatical rather than lexical meanings. In fact, conventionalized structures resulting from grammaticalization have in common a higher degree of abstractness: in this sense, morphemes are much more powerful semantic tools than lexemes, since they can convey a much wider spectrum of meanings. Possible deviations from centripetal directionality are far less frequent than the opposite processes of grammaticalization. They generally may be described in terms of an increase of periphericity with respect to the morphological core. The question why such an increase in periphericity takes place for certain elements must be however left for future research: we can only mention here Plank's (1992: 58) hypothesis according to which degrammaticalization reveals a disturbance in the system due to a discontinuity in language change. Future research will tell us if this discontinuity is due to chance or to deeper, and for the moment less foreseeable, reasons.

\section{Notes}

Parts of this chapter were presented at the annual SLE conference held in Poznan, 31 Aug.-2 Sept. 2000, and at the workshop on "Grammatikalisierung vs. Lexikalisierung" held in Konstanz, 1-3 Feb. 2001. I would like to thank the people present on these occasions for discussing parts of the paper with me, and especially Walter Bisang and an anonymous reviewer for fruitful comments on an earlier version of the paper. Needless to say, any errors still remaining are mine.

1. Consider in this perspective Haspelmath's (1999) attempt to conceive grammaticalization as an invisible-hand phenomenon following Keller (1990), accordingly caused in an unintentional manner by ordinary language use.

2. As for the Greek example, consider however the rather different interpretation provided by Joseph (2003: 484), who contends that "bearing in mind that the changes from thélō ( $h i)$ na to $\theta a$ all involve ordinary instances of phonetic change and analogy that resulted in increased separation from what ultimately became $\theta a$, the latter changes that result in $\theta a$ being a prefix are really incidental to the grammaticalization, rather than forming a crucial part of it that demonstrated that it occurred".

3. Quite distinct from these current usages is W. Lehmann's (1992: 224) definition of grammaticalization: "In the same way of improper clipping, inflectional markers have been produced in the process known as grammaticalization. One of the characteristic noun plural markers in German is -er, as in Kind "child", Kinder "children" ... In Pre-Old High German, finals of words were lost in such a way that -er survived in the plural, in contrast with its loss in the singular... It was then taken as a plural marker, and widely extended to many nouns". Indepedent of the inaccuracies contained in this explanation, we will treat in Section 2.1. below such changes as exaptations.

4. Although Joseph (2003) provides a number of criteria for distinguishing morphologization from grammaticalization (actually, strongly criticizing the very nature of the latter), he recognizes that the two types characterized as morphologization from above and morphologization from below "are actually quite similar, having the same outcome, that is morphology, and the same motivation. In particular, both reflect a preference on the part of the speakers for ... "localized" solutions to the problem of how to account for a given phenomenon in language, for example, marking for some category or a particular combinations of elements. "Localized" solutions range over small sets of data rather than being widely applicable, and are general only in a very local sense, covering perhaps just a few forms" (Joseph 2003: 473-474) 
5. On this subject, cf. the relevant observations by Janda (2003), who elaborates on the concept of phonetic distance as responsible for the loss of phonetic motivation, and consequently views phonologization (and possibly morphologization) as a "dephoneticization".

6. One could theoretically object that Lautsubstitutionen also are obligatory routines. However, what is hinted at here is rather that a context-driven automatic sound alternation is replaced by a context-independent morphophonemic rule. For instance, Germanic umlaut (see text) is shown to have begun as an automatic coarticulation rule affecting a low vowel when followed by a high front vowel (cf. Iverson and Salmons 1999).

7. Similarly, German umlaut is grammaticalized conveying causativity in the following verbs: lahmen 'to be lame' vs. lähmen 'to paralyze', dampfen 'to steam' vs. dämpfen 'to steam (cook.)', etc. (cf. Gaeta 1998: 95).

8. Although recently Haspelmath (1998) has strongly criticized the abuse of reanalysis in grammaticalization studies, I share Campbell's (2001) objections against his approach since Haspelmath's usage of reanalysis is rather idiosyncratic and falls outside the current view adopted by other grammaticalizationists who do consider reanalysis to be one of the most important mechanisms of grammaticalization, sharply distinguished from analogy (cf. Hopper and Traugott 1993: 56; Gaeta 1998, and in a different perspective Loporcaro 2001: 278).

9. An anonymous reviewer observes that the difference between the changes labelled as exptation with respect to the ones labelled as grammaticalization may be due to the relative chronology. If I understand the observation correctly, the difference in relative chronology (say, of the obscuring phonological change, and of the subsequent process of reanalysis) should explain why in the one case we obtain an exaptation, and in the other a grammaticalization. Albeit this might be true, it does not undermine the basic distinction drawn in the text between the creation of a new semiotic motivation, typical of grammaticalization, and the re-grammaticalization of already extant linguistic material, that is - according to Vincent - the main character of exaptation.

10. Cf. however Bisang (2001), who shows how such an endogenous process of infixcreation was blocked by language contact.

11. The Gorgia rule is presented here in a rather simplified way (for details $\mathrm{cf}$. Marotta 1995: 311-314). In fact, as for velar consonants Gorgia is implemented in different ways in the two varieties, respectively as lenition proper in Lucca and as complete deletion in Pisa.

12. For the particular set of features in the triggering context, RF reminds us of another similar sound alternation found in Welsh and usually counted among the socalled mutations (cf. Awbery 1986, Willis 1986): y gog ( $\leftarrow / \mathrm{k} / \mathrm{og}$ ) 'the cuckoo (F)' vs. $y \operatorname{cog}$ 'the cook (M)'. Here, the voicing of the initial consonant is triggered by the presence of the feminine definite article. Similar to RF, the Welsh lenition can be represented in the following way:

$$
\mathrm{C} \rightarrow[+ \text { voice }] /\left[\begin{array}{c}
- \\
+ \text { det } \\
+ \text { def } \\
+ \text { fem } \\
+ \text { sing }
\end{array}\right] \#
$$

13. Moreover, the possessed subject of a possessive clause is marked by lenition when it occurs after the possessor and opens the NP:

(i) [maj ki: gan *win]

'Wyn has a dog.' lit. 'Is a dog with Wyn'

(ii) [maj ki: *w1n gi:]

'Wyn has a dog' lit. 'Is with Wyn a dog'

The contextual conditions being the same, viz. initial position in the NP, what appears to be relevant here is the semantic content associated with the syntactic role of the constituent: in both cases, it is characterized by low agentivity and low thematicity. For a general discussion of the intricacies of the historical development of the Welsh facts, as well as of the wandering, i.e. the paradigmatic extension, of morphophonological alternations, cf. Comrie (2002).

14. We can also represent the difference between the cases discussed here and those of Section 2.2. (cf. for instance (14) above) in terms of the distinction between inherent and contextual inflection as developed by Booij (1996), according to which the cases treated here clearly go under the label of contextual inflection, whereas the former are instances of inherent inflection.

15. Consider for example Hagège (1992: 7), who after having observed that "[a]s opposed to other levels in the study of language - phonology, syntax and lexicon morphology is the domain of maximum differentiation", notices that "the search for language universals is closely related to typology: the most fundamental properties, shared by all languages, coexist with the type-specific properties, which are the scope of typology. However, this search will not lead to many substantive findings if applied to morphology. This is because the word, as the main unit dealt with by morphology, is subject, as regards its formal structure, to a great deal of variation across languages". However, as remarked by Joseph and Janda (1988: 204), "we know of no language that lacks both affixation and compounding; Chinese, for example, certainly has compound morphology. Furthermore, clitics and free morphemes (or words) which structure sentences also seem to be present in all languages".

16. Another group of examples related to shifts between center and border within morphology is what Lazzeroni (1998) calls phonomorphogenesis, namely the process whereby phonemic material is converted into morphemic material. Consider for instance the Romance plural formed by means of the suffix -ora as in Old Italian camp-ora 'fields', ort-ora 'gardens' (besides the expected camp-i, ort-i), extracted from Latin forms such as tempora 'times', that occurred in late Latin close to the new plural temp-i. The suffix is the result of a wrong segmentation of the stem. Similarly, in Eolic Greek from the alternation between the genitive singular 
eugéne-os (from an early form *eugenes-os) and the dative plural eugénes-si 'of a good birth, noble' a new suffix -essi was extracted due to a wrong segmentation, and extended to other stems such as pód-essi 'feet-DAT.PL', pánt-essi 'all-DAT.PL' (cf. respectively Attic Greek posí<*pod-si, pâsi <*pant-si).

17. One can object that insertion of -isc-in Italian is now related to a phonetic condition, viz. the occurrence of stress. However, the point is here that the occurrence of stress is in itself conditioned by morphology, and therefore not really phonetically motivated, as noted by Rudes (1980: 329), who assumes that "the verbal suffix $+V s c+\ldots$ came to serve as a vehicle for facilitating the spread of a specific productive stress pattern from non-finite and past finite verb forms to non-past finite verb forms". For such a kind of stress Hurch (1996) speaks of "morphoprosody".

\section{References}

Andersen, Henning

1973 Abductive and deductive change. Language 49: 567-595.

1980 Morphological change: Towards a typology. In Historical Morphology, Jacek Fisiak (ed.), 1-50. The Hague: Mouton.

Awbery, Gwenllian M.

1986 Survey of sandhi types in Welsh. In Sandhi Phenomena in the Languages of Europe, Henning Andersen (ed.), 415-433. Berlin/New York: Mouton de Gruyter.

Barz, Irmhild

1983 Wortbedeutung und Wortbildungsbedeutung. Zeitschrift für Germanistik 1: 65-69.

Bisang, Walter

2001 Areality, grammaticalization and language typology. On the explanatory power of functional criteria and the status of Universal Grammar. In Language Typology and Universals, Walter Bisang (ed.), 175-223. Berlin: Akademie-Verlag.

Booij, Geert

1996 Inherent versus contextual inflection and the split morphology hypothesis. In Yearbook of Morphology 1995, Geert Booij and Jaap van Marle (eds.), 1-16. Dordrecht: Kluwer.

Brunot, Ferdinand and Charles Bruneau

1949 Précis de grammaire historique de la langue française. 3rd edn. Paris: Masson.

Bybee, Joan L.

1985 Morphology. Amsterdam/Philadelphia: John Benjamins.

Campanelli, Bernardino

1896 Fonetica del dialetto reatino. Turin: Loescher.
Campbell, Lyle

1991 Some grammaticalization changes in Estonian. In Approaches to Grammaticalization, vol. 1, Elizabeth C. Traugott and Bernd Heine (eds.), 285-299. Amsterdam/Philadelphia: John Benjamins.

2001 What's wrong with grammaticalization? Language Sciences 23: 113 161.

Campbell, Lyle and Richard Janda

2001 Introduction: conceptions of grammaticalization and their problems. Language Sciences 23: 93-112.

Carabulea, Elena and Magdalena Popescu-Marin

1967 Exprimarea numelui de actiune prin substantive cu formă de infinitiv lung şi de supin. In Studii şi Materiale Privitoare la Formarea Cuvintelor în Limba Română, vol. 4, 277-320. Bucarest: Academy of the Socialist Republic of Romania.

\section{Comrie, Bernard}

2002 Morphonological alternations. Typology and diachrony. In Morphology 2002. Selected Papers from the 9th Morphology Meeting, Vienna 24-28 February 2000, Sabrina Bendjaballah, Wolfgang U. Dressler, Oskar E. Pfeiffer and Maria D. Voeikova (eds.), 73-89. Amsterdam/ Philadelphia: John Benjamins.

Dressler, Wolfgang U.

1977 Elements of a polycentristic theory of word formation. Wiener Linguistische Gazette 15: 13-32.

1980 A semiotic model of diachronic process phonology. Wiener Linguistische Gazette 22-23: 31-94.

1985 Morphonology. Ann Arbor: Karoma Press.

1996 A functionalist semiotic model of morphology. In Trubetzkoy's Or phan, Rajendra Singh (ed.), 67-83. Amsterdam/Philadelphia: John Benjamins.

Fischer, Iancu

1989 Rumänisch: Wortbildungslehre. In Lexikon der Romanistischen Linguistik, vol. 3, Günter Holtus, Michael Metzeltin and Christian Schmitt (eds.), 33-55. Tübingen: Niemeyer

Foulet, Lucien

1921 Comment ont évolué les formes de l'interrogation. Romania 47: $243-$ 348.

Gaeta, Livio

1998 Some remarks on analogy, reanalysis and grammaticalization. In The Limits of Grammaticalization, Anna Giacalone Ramat and Paul J. Hopper (eds.), 89-105. Amsterdam/Philadelphia: John Benjamins.

2002 Growth of symbols: The inexorable fate of diagrams. In Future Chal lenges for Natural Linguistics, Katarzyna Dziubalska-Kołaczyk and Jarek Weckwerth (eds.), 129-151. Munich: LINCOM. 
Greenberg, Joseph H.

1991 The last stages of grammatical elements: Contractive and expansive desemanticization. In Approaches to Grammaticalization, vol. 1, Elizabeth C. Traugott and Bernd Heine (eds.), 301-14. Amsterdam/Philadelphia: John Benjamins.

Gvozdanović, Jadranka

1986 Phonological domains. In Sandhi Phenomena in the Languages of Europe, Henning Andersen (ed.), 27-54. Berlin/New York: Mouton de Gruyter.

Hagège, Claude

1992 Morphological typology. In International Encyclopedia of Linguistics, vol. 3, William Bright (ed.), 7-8. New York/Oxford: Oxford University Press.

Haiman, John

1998 Possible origins of infixation in Khmer. Studies in Language 22: 597617.

Harris, Alice C. and Lyle Campbell

1995 Historical Syntax in Cross-Linguistic Perspective. Cambridge: Cambridge University Press.

Harris, Martin

1978 The Evolution of French Syntax. A Comparative Approach. London: Longman.

Haspelmath, Martin

1998 Does grammaticalization need reanalysis? Studies in Language 22: 315-351.

1999 Why is grammaticalization irreversible? Linguistics 37: 1043-1068.

Heine, Bernd

2003 On degrammaticalization. In Historical Linguistics 2001, Barry J. Blake and Kate Burridge (eds.), 163-179. Amsterdam/Philadelphia: John Benjamins.

Hopper, Paul J.

1994 Phonogenesis. In Perspectives on Grammaticalization, William Pagliuca (ed.), 29-45. Amsterdam/Philadelphia: John Benjamins.

Hopper, Paul J. and Elizabeth C. Traugott

1993 Grammaticalization. Cambridge: Cambridge University Press.

Hurch, Bernhard

1996 Morphoprosody: Some reflections on accent and morphology. In Trubetzkoy's Orphan, Rajendra Singh (ed.),189-221. Amsterdam/Philadelphia: John Benjamins.

Iverson, Gregory K. and Joseph C. Salmons

1999 Umlaut as regular sound change: The phonetic basis of 'ingenerate umlaut'. In Language Change and Typological Variation: In Honor of Winfred P. Lehmann on the Occasion of His 83rd Birthday, Edgar C. Polomé and Carol F. Justus (eds.), 207-224. Washington: Institute for the Study of Man.
Janda, Richard D.

2001 Beyond "pathways" and "unidirectionality": On the discontinuity of language transmission and the counterability of grammaticalization. Language Sciences 23: 265-340.

2003 "Phonologization" as the start of dephoneticization - Or, on sound change and its aftermath: Of extension, generalization, lexicalization, and morphologization. In The Handbook of Historical Linguistics, Brian D. Joseph and Richard D. Janda (eds.), 401-422. Oxford: Blackwell.

Joseph, Brian D.

2001 Is there such a thing as "grammaticalization"? Language Sciences 23: 163-186.

2003 Morphologization from syntax. In The Handbook of Historical Linguistics, Brian D. Joseph and Richard D. Janda (eds.), 472-492. Oxford: Blackwell.

Joseph, Brian D. and Richard D. Janda

1988 The how and why of diachronic morphologization and demorphologization. In Theoretical Morphology, Michael Hammond and Michael Noonan (eds.), 193-210. New York: Academic Press.

Keller, Rudi

1990 Sprachwandel: Von der unsichtbaren Hand in der Sprache. Tübingen: Francke.

Klausenburger, Jürgen

1979 Morphologization: Studies in Latin and Romance Morphophonology Tübingen: Niemeyer.

1994 Morphologization. In The Encyclopedia of Language and Linguistics, R. E. Asher (ed.), 2562-2567. Oxford: Pergamon.

2000 Grammaticalization. Studies in Latin and Romance Morphosyntax. Amsterdam/Philadelphia: John Benjamins.

\section{Lazzeroni, Romano}

1998 Fonomorfogenesi. In Sintassi storica. Atti del XXX Congresso della Società di Linguistica Italiana, Paolo Ramat and Elisa Roma (eds.), 75 82. Rome: Bulzoni.

Léard, Jean-Marcel

1996 Til-tu, est-ce que, qu'est-ce que, ce que, hé que, don: Des particules de modalisation en français? Revue québécoise de linguistique 24: 107124.

Lehmann, Christian

1995 Thoughts on Grammaticalization. Unterschleissheim: Lincom.

Lehmann, Thomas

1998 Old Tamil. In The Dravidian Languages, Sanford B. Steever (ed.), 7599. London: Routledge.

Lehmann, Winfred $\mathrm{P}$

1992 Historical Linguistics. 3rd edn. London: Routledge. 
Loporcaro, Michele

1995 Raddoppiamento fonosintattico dopo III persone plurali del verbo nei dialetti di Conflenti (CZ) e San Giovanni in Fiore (CS). Rendiconti della Classe di Scienze Morali, Storiche e Filologiche dell'Accademia Nazionale dei Lincei, s. 9, v. 6, 543-553.

1997 L'origine del raddoppiamento fonosintattico. Basel: Francke.

2001 Rules vs. constraints in modeling phonological change: the case of Raddoppiamento Fonosintattico. In Constraints and Preferences, Katarzyna Dziubalska-Kołaczyk (ed.), 269-290. Berlin/New York: Mouton de Gruyter.

Luraghi, Silvia

1998 On the directionality of grammaticalization. Sprachtypologie und Universalienforschung (STUF) 51:355-365.

Marotta, Giovanna

1995 Apocope nel parlato di Toscana. Studi Italiani di Linguistica Teorica e Applicata 24: 297-322.

Matisoff, James A

1991 Areal and universal dimensions of grammaticalization in Lahu. In Approaches to Grammaticalization, Elizabeth Traugott and Bernd Heine (eds.), 383-453. (Vol. 2.) Amsterdam/Philadelphia: John Benjamins.

\section{McMahon, April}

1994 Understanding Language Change. London: Routledge.

Morin, Yves-Charles

1986 On the morphologization of word-final consonant deletion in French. In Sandhi Phenomena in the Languages of Europe, Henning Andersen (ed.), 167-210. Berlin/New York: Mouton de Gruyter.

Morin, Yves-Charles, Marie-Claude Langlois and Marie-Ève Varin

1990 Tensing of word-final [0] to [o] in French: The Phonologization of a morphophonological rule. Romance Philology 43: 507-528

Newmeyer, Frederick J.

1998 Language Form and Language Function. Cambridge, MA: MIT Press. Norde, Muriel

2001 Deflexion as a counterdirectional factor in grammatical change. Language Sciences 23: 231-264.

Picard, Marc

1992 Aspects synchroniques et diachroniques de $t u$ interrogatif en québécois. Revue québécoise de linguistique 21: 65-75.

Plank, Frans

1992 From cases to adpositions. In Aspects of English Diachronic Linguistics, Nicola Pantaleo (ed.),19-61. Fasano: Schena.

Ronneberger-Sibold, Elke

1990 Zur Verselbständigung sprachlicher Einheiten: Der deutsche Umlaut. In Spielarten der Natürlichkeit - Spielarten der Ökonomie. Beiträge zum 5. Essener Kolloquium, Norbert Boretzky and Thomas Stolz (eds.), 185-205. (Vol. 2.) Bochum: Brockmeyer.
Rudes, Blair A.

1980 The functional development of the verbal suffix $+e s c+$ in Romance In Historical Morphology, Jacek Fisiak (ed.), 327-348. The Hague: Mouton

Steever, Sanford B.

1987 Tamil and the Dravidian languages. In The World's Major Languages, Ternes, Elmar Bernard Comrie (ed.), 725-756. London: Routledge.

1986 A grammatical hierarchy of joining. In Sandhi Phenomena in the Languages of Europe, Henning Andersen (ed.), 11-21. Berlin/New York: Mouton de Gruyter.

van Coestem, Frans and Susan McCormick

1990 Morphophonology. In Research Guide on Language Change, Edgar C. Polomé (ed.), 325-345. Berlin/New York: Mouton de Gruyter.

Vincent, Nigel

1995 Exaptation and grammaticalization. In Historical Linguistics 1993 Henning Andersen (ed.), 433-445. Amsterdam/Philadelphia: John Benjamins.

Willis, Penny

1986 The Initial Consonant Mutation in Welsh and Breton. Bloomington: Indiana University Linguistic Club.

Wurzel, Wolfgang Ullrich

1980 Ways of morphologizing phonological rules. In Historical Morphology, Jacek Fisiak (ed.), 443-462. The Hague: Mouton.

2000 Gegenstand der Morphologie. In Morphologie. Ein internationales Handbuch zur Flexion und Wortbildung, Geert Booij, Christian Lehmann and Joachim Mugdan (eds.), 1-15. Berlin/New York: de Gruyter. 